\title{
琉球石灰岩帯水層における脱窒に係わる微生物相解析
}

\author{
安元 純 $^{*}$. 廣瀬 (安元) 美奈 ${ }^{* * * * *}$. 久手堅剛 $* * *$. 宮城雄次 ${ }^{* * *}$. \\ 大城要平 $* * *$. 聖川健斗 $* * *$ * 細野高啓 $* * * *$. 嶋田 純*******中野拓治*
}

\section{Microbial community analysis of groundwater related to the denitrification in Ryukyu limestone aquifer}

\author{
Jun YASUMOTO* , Mina YASUMOTO-HIROSE**,**, Tsuyoshi $\operatorname{KUDEKEN}^{* * *}$, \\ Yuuji MIYAGI $* * *$, Yohei OSHIRO $* * *$, Kento HIJIKAWA ****, \\ Takahiro HOSONO *****, Jun SHIMADA $* * * * *$ and Takuji NAKANO*
}

\begin{abstract}
This study explores the use of microbial community analysis to evaluate the processes involved in nitrate attenuation in groundwater. Polymerase chain reaction (PCR)-denaturing gradient gel electrophoresis (DGGE) is used to identify denitrifiers based only on their 16SrRNA gene sequences, and Real-Time PCR analysis is used to quantify nitrite reducing genes (nirK and nirS). The latter suggest a new method to be used for detecting denitrification activity by comparing the gene dosage that has been detected by Real-Time PCR and the value of the nitrate $\left(\mathrm{NO}_{3}{ }^{-}\right) \delta^{15} \mathrm{~N}$ and $\delta^{18} \mathrm{O}$. This study focuses on a zone of significant $\mathrm{NO}_{3}{ }^{-}$attenuation occurring at underground dam catchment area in the karstic Ryukyu limestone aquifer, which is located in the southern part of Okinawa, Japan.

As a result of microbial analysis, the bacteria were detected at all observation points which have been reported to have denitrification ability. And it has been confirmed that the bacteria has a gene nirS which is related to denitrification. In addition, the correlation was high between nirK /nirS gene dosage that has been detected by Real-Time PCR and the value of the nitrate $\delta^{15} \mathrm{~N}$ and $\delta^{18} \mathrm{O}$; therefore, this study demonstrates the effectiveness of using Real-Time PCR analysis for providing insights into the processes affecting nitrate attenuation in groundwater.
\end{abstract}

Key Words: denitrification, microbial community analysis, groundwater, Ryukyu limestone

琉球大学農学部 ( $\bar{T} 903-2213$ 沖縄県中頭郡西原町字千原1番地)

Faculty of Agriculture, University of the Ryukyus

一般社団法人トロピカルテクノプラス

Tropical Technology Plus.

株トロピカルテクノセンター

Tropical Technology Center Ltd.

琉球大学大学院 農学研究科

Graduate School of Agriculture, University of the Ryukyus

熊本大学大学院先導機構

Priority Organization for Innovation and Excellence, Kumamoto University

熊本大学大学院 自然科学研究科

Graduate School of Science and Technology, Kumamoto University 


\section{要旨}

本研究では, 沖縄本島南部地域の琉球石灰岩帯水層に打いて, 地下水水質デー夕と硝酸中の窒素及 び酸素同位体比 $\left(\delta^{15} \mathrm{~N}_{\mathrm{NO}_{3}}, \delta^{18} \mathrm{O}_{\mathrm{NO}_{3}}\right)$ を測定することで脱窒ポイントを推定し, PCR 法を組み合わせ た変性剂濃度勾配ゲル電気泳動法（以下, PCR-DGGE 法) 及びリアルタイム PCR 等を用いた微生物 相解析等を実施して, 帯水層中の優占種㧍よび分離菌株の分子系統解析と脱窒関連遺伝子の検出と 定量を試みると共に, その結果と $\delta^{15} \mathrm{~N}_{\mathrm{NO}_{3}}, \delta^{18} \mathrm{O}_{\mathrm{NO}_{3}}$ の結果を比較し, 地下水中の脱窒の有無やその程度 の推定に対する微生物相解析の有効性について検討した。

その結果, 細菌種は異なるものの, 脱窒ポイント, その他のポイントに係わらず, 全観測地点で脱 窒能を持つと報告されている属と同じ属の細菌が検出された。リアルタイム PCRを用いて脱窒関連 遺伝子 (nirS/nirK) の定量を行ったところ, nirK 遺伝子に比べ nirS 遺伝子の方が多く検出され, 本 地域の脱窒には nirS 遺伝子をもつ微生物が優先的にかかわっていることが明らかとなった。さらに, nirS 及び nirK 遺伝子の DNA コピー数と $\delta^{15} \mathrm{~N}_{\mathrm{NO}_{3}}, \delta^{18} \mathrm{O}_{\mathrm{NO}_{3}}$ の值との間には比較的高い相関がみられ, $\delta^{15} \mathrm{~N}_{\mathrm{NO}_{3}}, \delta^{18} \mathrm{O}_{\mathrm{NO}_{3}}$ を用いた同位体的手法とリアルタイム PCR 用いた脱窒関連遺伝子の定量手法を併 用することが, 地下水中における脱窒環境やその程度を推定する有効な手法となる可能性が示唆さ れた。

\section{1. はじめに}

带水層における脱窒は, 硝酸イオン $\left(\mathrm{NO}_{3}{ }^{-}\right)$ を含む好気的環境と酸素を含まない嫌気的環境 の境界付近で, 独立栄養または従属栄養の脱窒 菌が存在し, 電子供与体 (易分解性の有機炭素 (OC) やパイライト $\left.\left(\mathrm{FeS}_{2}\right)\right)$ が存在するときに 局所的に進行することが知られている（江口, 2012)。現場の地下水中で脱窒を定性的・定量的 に評価する場合，脱窒の有無を検証するための 複数の直接的 ・間接的証拠を積み上げられるこ とが多い（江口，2008）。例えば, $\mathrm{NO}_{3}{ }^{-}$や溶存酸 素（DO）や酸化還元電位（ORP）, 重炭酸イオン $\left(\mathrm{HCO}_{3}{ }^{-}\right)$等の脱窒の状況証拠となる地下水水質 データにくわえ, 脱窒の副産物として生成する各 種ガス $\left(\mathrm{N}_{2} \mathrm{O}, \mathrm{N}_{2}\right)$ と地下水中で安定な溶存ガス (Ar) の濃度比, 溶質トレーサー $\left(\mathrm{Cl}^{-}, \mathrm{Br}^{-}\right)$や 数值モデルを用いて, 脱窒の有無やその程度が 推定される（江口，2008）。くわえて, $\mathrm{NO}_{3}{ }^{-}$中の 窒素の安定同位体比 $\delta^{15} \mathrm{~N}$ は, 脱窒に伴う同位体 分別による濃縮が生じることから, 脱窒の有効 な指標として古くから利用されてきた（Mariotti, 1986; Mariotti et al., 1988; Böhlke and Denver, 1995; Widory et al., 2005)。近年では, $\mathrm{NO}_{3}{ }^{-}$中の $\delta^{15} \mathrm{~N}$ にくわえ, $\mathrm{NO}_{3}{ }^{-}$中の酸素の安定同位体比 $\delta^{18} \mathrm{O}$ を測定することで, 二成分の解析から, よ り詳細に窒素の起源や脱窒の有無やその程度を 検討することが可能となっている（Kendall et al., 2007)。さらに, 最近では, 硝酸中の $\delta^{15} \mathrm{~N} や \delta^{18} \mathrm{O}$
以外にも, 各種安定同位体比 $\left(\delta^{13} \mathrm{C}, \quad \delta^{15} \mathrm{~N}, \quad \delta^{34} \mathrm{~S}\right.$ and $\left.\delta^{18} \mathrm{O}\right)$ を同時に測定し, 脱窒にくわえ硫酸 還元の有無や, 従属型脱窒あるいは独立栄養型 脱窒を識別する試みもみられるようになってい る (Torrentó et al., 2011; Heffernan et al., 2012; Hosono et al., 2014)。

一方, 近年, 分子生物学的手法を用いた遺伝子 解析技術が, 環境中に存在する微生物相解析に 応用され, 地下水などの水環境中における微生 物相が徐々に明らかにされつつある。脱窒に関 しても研究が進んできており，これまで脱窒菌 とひとくくりにされていた脱窒能をもつ微生物 が, 細菌, 古細菌および糸状菌を含む広範囲の 微生物により行われていることや（Tiedje, 1994; Philippot et al., 2007; Hayatsu et al., 2008)，系統分 類上多岐にわたっていることが明らかになってい る (Katsuyama et al., 2008; Jones et al., 2012)。そ のため, 脱窒に関わる細菌の検出のために, 亜硝 酸還元酵素 (nirK, nirS) や $\mathrm{N}_{2} \mathrm{O}$ 還元酵素 (nos Z) の遺伝子をマーカーにした遺伝子解析等も実施 されている (Braker et al., 1998; Rich et al., 2003; Throbäck et al., 2004)。つまり，上述した各種安 定同位体比に加え, 遺伝子解析等によりその場の 微生物相と単離・培養された細菌の脱窒に関わる 遺伝子の有無を直接確かめることが，带水層にお ける脱窒による窒素除去量を推定するための有益 な情報となりえる。しかし，地下水中における脱 窒に関して, 上述したような分子生物学的手法 と, 従来の, 地下水水質や各種安定同位体比との 
関係性について検証された例はほとんどみられな w。

本研究の調査対象地域である沖縄本島南部地域 では，農業用水の確保を図るため，糸満市及び八 重瀬町の1352ha の畑地を対象に国営沖縄本島南 部水利事業が1992年～2005年にかけて実施されて いる。それにより, 米須と慶座の 2 カ所に築造さ れた地下ダムによって琉球石灰岩帯水層に貯留さ れている地下水が新たな水資源として開発され, 2006年から農業用水に地下水が利用されている。 これまで, 琉球石灰岩帯水層において地下水中の 脱窒に係る微生物相について遺伝子解析された例 はないが，今後，本地域の地下水の持続的な利用 や周辺の海域環境保全に資する観点からも, 琉球 石灰岩带水層中における脱窒量を正確に見積もる 必要があり, 微生物相解析から得られる情報は非 常に有益となる。

そこで本研究では, 沖縄本島南部地域の琉球石 灰岩帯水層に抏いて, 地下水水質デー夕と硝酸中 の窒素及び酸素同位体比 $\left(\delta^{15} \mathrm{~N}_{\mathrm{NO}_{3}}, \quad \delta^{18} \mathrm{O}_{\mathrm{NO}_{3}}\right)$ を 測定することで脱窒ポイントを推定し, PCRDGGE 及びリアルタイム PCR 等を用いた微生物 相解析等を実施して, 带水層中の優占種および分 離菌株の分子系統解析と脱窒関連遺伝子の検出と 定量を試みると共に, その結果と $\delta^{15} \mathrm{~N}_{\mathrm{NO}_{3}}$, $\delta^{18} \mathrm{O}_{\mathrm{NO}_{3}}$ の結果を比較し, 地下水中の脱窒の有無 やその程度の推定に対する微生物相解析の有効性 について検討した。

\section{2. 調查研究概要}

\section{1 地形・地質および土地利用状況}

地形地質に関する詳細は, 安元ほか（2013）を ご参照頂きたいが，以下に要約して記述する。

沖縄本島南部地域の地形は, 琉球層群を表層地 質とする段丘地形によって特徵づけられる。河川 の発達は見られず，地域内には断層が縦横に発達 し断層崖に沿って長く続くリッジ状の丘が多く点 在している。

地質は, 新第三紀鮮新世の島尻層群を基盤とし て，第四紀更新世の琉球層群が不整合に覆ってい る。琉球層群は隆起サンゴ礁や有孔虫を由来とす る堆積岩で空隙に富み極めて高い透水性を有して
おり, 琉球石灰岩と呼ばれている。地下水は難透 水性地盤の島尻層群を受け㿼として, 多孔質の琉 球石灰岩中に賦存され, 地下水盆を形成している (木崎, 1985)。

土地利用に関しては, 沖縄本島南部地域は, 那 覇市に近接する糸満市, 八重瀬町, 南城市の畑地 農業地域であり, 調査地域一面にはサトウキビ畑 が広がっている。近年, 地下ダムによる灌溉用水 の利便性の増加から, 電照菊等の花卉類の栽培も 増えている。糸満市の污水処理は, 主に, 公共下 水道（単独）であり, 污水処理施設の普及率は, 平成23年末で70 90\%とされているため, 地下水 への窒素の負荷源として生活排水の流入も予想さ れる。また, 一部に畜産施設もみられる。

\section{2 調查・分析方法}

図 1 に本研究で行う帯水層の脱窒の有無および 微生物相解析に関するフローチャートを示した。 まず，本調査地域において，以下 2.2 .1 に示す 地下水水質データと $\delta^{15} \mathrm{~N}_{\mathrm{NO}_{3}}, \delta^{18} \mathrm{O}_{\mathrm{NO}_{3}}$ から脱窒の 有無を推定し, 観測地点（No.1〜 No.7）を脱窒 ポイントとその他のポイントに分類した。微生物 相解析では, 採取した地下水試料を上清 (地下水) と沈殿物（懸濁物質）に分離し，それぞれDNA 抽出及び細菌の単離・培養を実施した。抽出した DNA を用いて PCR-DGGE により地下水試料の上 清及び沈殿物に存在している細菌相のバンドパ ターンによる可視化を行った。くわえて，地下水 試料の上清中から検出された単一バンド（単一優 占株）のDNAを抽出し, シーケンス解析を行い 細菌の系統解析を行った。一方, 地下水が最も還 元的で, $\delta^{15} \mathrm{~N}_{\mathrm{NO}_{3}}, \quad \delta^{18} \mathrm{O}_{\mathrm{NO}_{3}}$ からも脱窒が確認され た脱窒ポイントの地下水試料の上清及び沈殿物か ら細菌を単離・培養した。単離・培養した細菌は,

MALDI-Biotyperを用いて系統解析を行うと共に DNAを抽出し, 脱窒関連の遺伝子 (nirS/nirK) を有しているか確認した。さらに, リアルタイム PCR を用いた脱窒関連の遺伝子 (nirS/nirK) の 定量を, 各地点の地下水試料の上清と沈殿物につ いて行った。

\section{2.1 地下水水質データ及び $\delta^{15} \mathrm{~N}_{\mathrm{NO}_{3}}$, $\delta^{18} \mathrm{O}_{\mathrm{NO}_{3}}$ の分析}

本研究では, 調査対象地域に分布する湧水及 


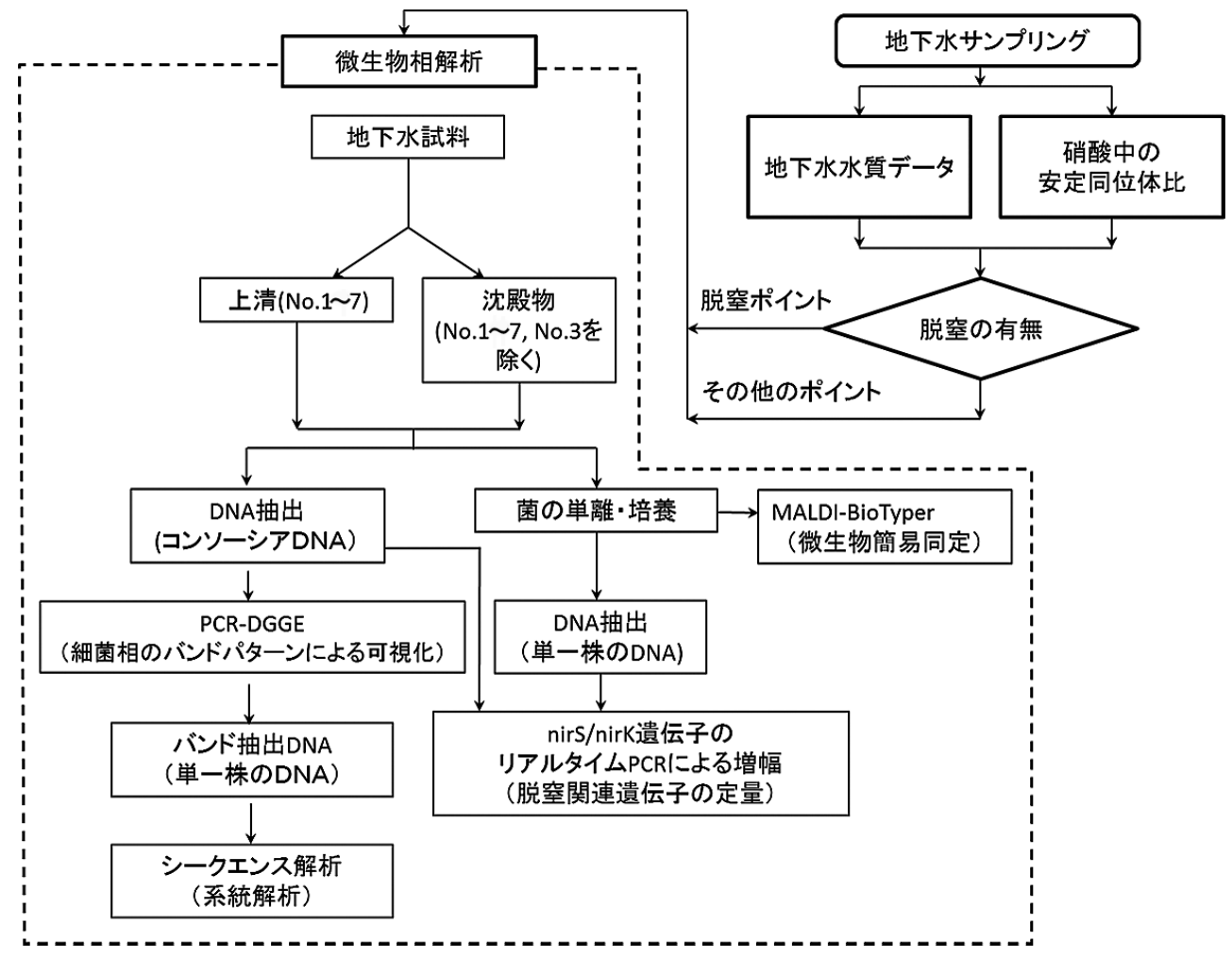

図 1 帯水層中の脱窒に係わる微生物相解析に関するフローチャート

Fig. 1 Flowchart of microbial analysis related to denitrification in Ryukyu limestone aquifer

び，沖縄総合事務局が地下ダムを築造する際に設 置した観測井（基盤岩に到達するまで全面的にス トレーナーを配置）を利用し，図 2 に示す25地 点（湧水：5力所, 観測井 : 20 力所）で地下水の 採水を実施した。その内, 図中に示したNo.1〜 No.7の地点 (湧水 : 1 力所, 観測井 : 6 力所) に おいて微生物相解析のための採水を実施した。地 下水調査は2012年12月25日～27日に実施した。

観測井における地下水位の確認にはミリオン水 位計を用い, 確認された地下水面から $-5 \mathrm{~m}$ 付近 の地下水をべーラーを用いて採水した。

現地測定項目は, 水温, $\mathrm{pH}$, 電気伝導度 (EC), 酸化還元電位 (ORP), 溶存酸素 (DO) とし，採水した地下水及び湧水を地表にて大気雲 囲気下で測定した。室内水質測定項目は, 陽イオ ン $\left(\mathrm{Na}^{+}, \mathrm{K}^{+}, \mathrm{Mg}^{2+}, \mathrm{Ca}^{2+}\right)$, 陰イオン $\left(\mathrm{Cl}^{-}\right.$, $\left.\mathrm{NO}_{3}{ }^{-}, \mathrm{SO}_{4}{ }^{2-}\right)$, 重炭酸イオン $\left(\mathrm{HCO}_{3}{ }^{-}\right)$とした。 溶存有機炭素（DOC）に関しては, 2012年 9 月 23日〜24日に採水した試料について測定した。
各種測定に使用した機器は, $\mathrm{pH}, \mathrm{EC}, \mathrm{ORP} 及$ びDO の測定には，pHメータ D-54及び D-55（堀 場製作所社製) を用いた。主要な陽・陰イオンに 関しては，イオンクロマトグラフ（DIONEX ICS1600), $\mathrm{HCO}_{3}{ }^{-}$に関しては，現地で， $\mathrm{HACH}$ 社製 のデジタルタイトレータを用いアルカリ度滴定法 にて行った。DOCに関しては TOC-L (株)島津製 作所社製）を用いた。

$\delta^{15} \mathrm{~N}_{\mathrm{NO}_{3}}, \quad \delta^{18} \mathrm{O}_{\mathrm{NO}_{3}}$ の測定は脱窒菌法 (Sigman et al., 2001）を用いて行った。本手法は, 硝酸イオ ンを亜硝酸ガスまで還元する能力を持つ脱窒菌 (Pseudomonas aureofaciens) による生物的還元作 用を用いてサンプル中の硝酸イオンから亜硝酸ガ スを生成し，質量分析計を用いて行うものである (Kendall et al., 2007)。分析には熊本大学の安定 同位体比測定用質量分析計 Delta V (Thermo Electron 社製）を用いた。

\section{2.2 地下水の DNA 抽出前処理}

微生物相解析のための地下水調査は, 2012年 


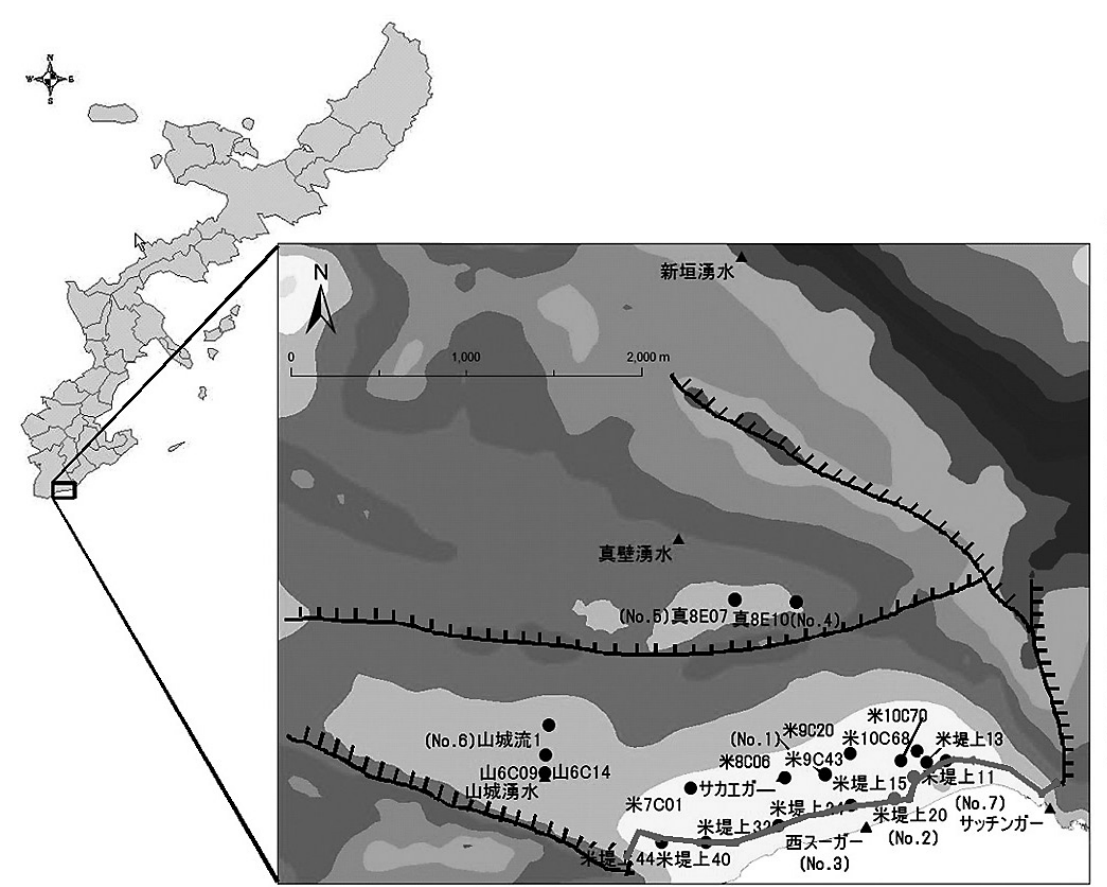

注)赤色は微生物相解析対象地点

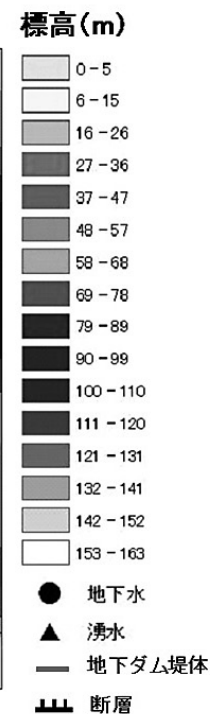

図 2 地下水採水地点図

Fig. 2 Sampling points of groundwater
12月25日〜27日に実施した。滅菌処理済み2L ポ リ容器に採水した試料は実験室に戻り,すみや かにフィルターろ過器 CN メンブレンフィルター ユニット（孔径 $0.2 \mu \mathrm{m}$, Membrane Filter Units,

Cellulose Nitrate Membrane, NALGENE ${ }^{\circledR}$ 社製) を使って処理した。サンプルボトルを30分程度 静置したのち, 試料の上清 $2.29 \mathrm{~L}$ （地下水 $2.29 \mathrm{~L}$ 中 の懸濁物質の体積は, その体積が多い箇所でも $1.5 \mathrm{~mL}$ 程度）をろ過後に, フィルターろ過器の フィルターをスパーテルで切り取り, 滅菌した $5 \mathrm{~mL}$ の TE 緩衝液（TE Buffer Solution, pH8.0, 滅 菌, バイオテクノロジグレード, nacalai tesque 社製）が入った $15 \mathrm{~mL}$ チューブに浸漬し，擋拌・ 懸濁した。懸濁液をDNA 抽出用試料とした。懸 濁体の沈殿部分 (以後, 懸濁物質 : P) は, 滅菌 した50mLのチューブに取り，3000rpm で15分間 遠心し, 沈殿物を滅菌した $1.5 \mathrm{~mL}$ のチューブに移 し替え, $3600 \times \mathrm{g}$ で 2 分間遠心した後, 上清部分 を取り除き, 懸濁物質試料とした。DNA 抽出条 件の検討は試料を $-80^{\circ} \mathrm{C}$ で数日間保存した後に
行った。

\section{2. 3 DNA 抽出}

DNA 抽出条件の検討は, 標準 eDNA 解析マ ニュアル（農業環境技術研究所, 2010）に従い, FastDNA SPIN Kit for Soil（Q-BioGene 社製）を 用いた。破砕装置にチューブをセットして, $1500 \mathrm{rpm}$ で60秒間破砕処理を行い DNAを抽出し た。抽出したDNAは，アガロースゲル電気泳動 で確認し, 細菌16S rRNA 遺伝子の PCR を行い DGGEによって菌相解析を行った。直ちに使用 しない場合は, DNA 溶液は $-30^{\circ} \mathrm{C}$ で凍結保存し た。

\section{2.4 PCR（遺伝子増幅）}

PCR は, Takara 社製の PCR Thermal Cycler SP およびASTEC 社製 Program Temp. Control System PC818を用い, 条件の検討はこれまで の報告を基に行った（農業環境技術研究所, 2010 ; Muyzer et al., 1993 ; Yasumoto-Hirose et al., 2006)。一般細菌相用の解析用プライマーと して, 真正細菌16S rRNA 遺伝子のV3可変領域 
を標的とする以下のプライマーセットを使用し た。地下水試料の上清および沈殿物それぞれ で, 341FGC, 5'-cgc ccg ccg cgc gcg gcg ggc ggg gcg ggg gca cgg ggg gcc tac ggg agg cag cag-3’ (下線部は GC clamp)，534R，5'- att acc geg gct gct gg-3’，を用いて PCR 増幅した遺伝子断片を DGGE 解析した。PCRの各条件は以下に示す。 1stPCR-KOD-Plus-Neo: 反応液組成 $(50 \mu \mathrm{L}$ 反応 系) 滅菌蒸留水 $33 \mu \mathrm{L}, 10 \mathrm{xKOD}$ Plus-Neo Buffer $5 \mu \mathrm{L}, \quad \mathrm{dNTPs}(2 \mathrm{mM}) 5 \mu \mathrm{L}, \mathrm{MgSO}_{4}(25 \mathrm{mM})$ $2 \mu \mathrm{L}, 341 \mathrm{FGC}(10 \mu \mathrm{M}) 1 \mu \mathrm{L}, 534 \mathrm{R}(10 \mu \mathrm{M})$ $1 \mu \mathrm{L}, \quad B S A(20 \mathrm{mg} / \mathrm{mL}) 1 \mu \mathrm{L}$, KOD-Plus-Neo $1 \mu \mathrm{L}$, Template DNA $1 \mu \mathrm{L} 。 1$ stPCR 反応サイク ルは, $95^{\circ} \mathrm{C}-3$ 分 $\rightarrow\left[94^{\circ} \mathrm{C}-15\right.$ 秒, $57^{\circ} \mathrm{C}-30$ 秒, $68^{\circ} \mathrm{C}-15$ 秒] を33サイクル。2ndPCR-KOD-Plus$\mathrm{Neo}$ ：反応液組成（上記記載）。応サイクルは, $95^{\circ} \mathrm{C}-3$ 分 $\rightarrow\left[94^{\circ} \mathrm{C}-15\right.$ 秒, $55^{\circ} \mathrm{C}-30$ 秒, $68^{\circ} \mathrm{C}-$ 15秒]を30または33サイクル。鋳型 DNAを加え ないネガティブコントロールを必ず設けた。

\subsection{5 変性剂濃度勾配 ゲル電気泳動 (DGGE) 解析}

DGGEは，BioRad社製 D-code system を用い, 変性剂高濃度 $(70 \%)$ 及び変性剂低濃度 $(50 \%)$ のゲルストック溶液を調整し, DCodeのマニュ アルに従い行った。泳動槽温度 $58^{\circ} \mathrm{C}$, 電圧 $50 \mathrm{~V}$, 泳動時間18時間の条件で泳動した。また，パター ンの比較を容易にするために, マーカー（DGGE Marker III, ニッポンジーン）レーンを設けた。 SYBR Green で染色し，ルミノ・イメージアナラ イザーLAS-3000（FUJIFILM 社製）装置を用い て染色したゲルを撮影した。ゲルからメスでバン ドを切り出し, $100 \mu \mathrm{L}$ の TE 緩衝液が入った滅菌 チューブに入れて，一晚振とう後，DNAを抽出 した。抽出したDNAはPCRにより遺伝子を増 幅させた。PCR 産物 $3 \mu \mathrm{L}$ をアガロースゲルで電 気泳動して期待サイズ（約193bp）の産物が得ら れていることを確認した。抽出したDNAが単一 のバンドになるまで，DGGEを繰り返した。す ぐに DGGEを行わない場合, 抽出産物は $-30^{\circ} \mathrm{C}$ 以下で保存した。

\section{2.6 シークエンス解析}

DGGE によって分離されたDNA 断片の塩基配 列を BigDye ${ }^{\circledR}$ Terminator v3.1 Cycle Sequencing
Kit (Applied Biosystems) を用い, DNA シーク エンサー (ABI PRISM 3100 Genetic Analyzer, Applied Biosystems）を用いて決定した。得られ た配列をDNA データベースと照合して相同性検 索（BLAST 検索）(Altschul et al., 1997）を行い, 地下水中の微生物に近縁な細菌を予測した。地下 水 7 試料の上清（S1〜 S7） から20バンドの塩基 配列情報を得ることができた。

\section{2.7 MALDI-TOF MS（地下水からの菌の 単離)}

地下水上清および懸濁物質から細菌を単離し た。細菌の単離は, 各試料 $50 \mu \mathrm{L}$ を 3 種の培地に 滅菌コンラージ棒（日水製薬株式会社製）で塗 抹することにより行った。培地の組成は以下に 示した。（1）NB: Nutrient Broth (Difco 社製) $8 \mathrm{~g}$, 蒸留水 $1 \mathrm{~L}$, 寒天濃度は $1.5 \%$ に調整した。 （2）MB : Marine Broth（Difco 社製）37.4g, 蒸留水 $1 \mathrm{~L}$, 寒天濃度は $1.5 \%$ に調整した。（3） 1/10MB: Marine Broth (Difco 社製) $3.74 \mathrm{~g}$, 人工 海水 $750 \mathrm{~mL}$, 蒸留水 $250 \mathrm{~mL}$, 寒天濃度は $1.5 \%$ に 調整した。生えてきたコロニーは新たな培地に植 菌し, 単菌化ができた細菌についてマトリックス 支援レーザー脱離イオン化飛行時間型質量分析計 （以下, MALDI-TOF MS）による解析を行った。 培地から培養 4 日目のプレートコロニーを滅菌し た楊枝で少量かきとり, ターゲットプレートに薄 く均一になるように塗布した。HACCマトリック ス (Bruker 社製) 溶液を $1 \mu \mathrm{L}$ 添加し乾燥させた。 キャリブレーションスタンダードは, Bruker Bacterial Test Standard（Bruker 社製）を使用した。 MALDI-Biotyper は ultrafleXtreme(Bruker Daltonics 社製）の MALDI-TOF-MS（Matrix-assisted laser desorption/ionisation-time of flight mass spectrometry）を使用した。

MALDI-Biotyperは，すべての微生物に存在す る含有量の多いタンパク質を測定し, タンパク質 の固有のパターンを多数の菌種が登録されている データベースとマッチングさせることで，信頼性 が高くかつ正確に微生物を同定し, 種レベルで菌 名を決定する手法である。分析速度が他の手法に 比べて早く簡便であり, シークエンス解析に比べ て安価である。スコア值が 2.0 以上であれば菌種 
レベルで信頼性が高く, 1.7以上2.0未満では属レ ベルと一致するとされている（大楠，2012）。

\section{2. $2.8 \mathrm{nirS} \cdot \mathrm{nirK}$ 遺伝子の増幅}

リアルタイム PCR 法を用いて, 地下水から抽 出したDNAに含まれる, 脱窒反応に係わる遺 伝子 nirS, nirKの定量を行った。PCR 反応での プライマーは, nirS 遺伝子に m-Cd $3 \mathrm{aF} / \mathrm{m}-\mathrm{R} 3 \mathrm{Cd}$ (Kandeler et al., 2006)， nirK 遺伝子に nirK876F/ nirK1040R（Henry et al., 2004）を使用した。 PCR 反応溶液 $(20 \mu \mathrm{L})$ の組成は, $2 x$ FastStart Essential DNA Green Master (Roche Diagnostics 社製） $10 \mu \mathrm{L} ，$ プライマー $\mathrm{F}, \mathrm{R}$ それぞれ $0.2 \mathrm{mM}$, $\mathrm{BSA} 400 \mathrm{ng} / \mu \mathrm{L}$ となるよう調整し, DNA 溶液 $1 \mu \mathrm{L}$ を加えた。PCR 反応条件は Henry et al. （2004）の報告に従い， LightCycler 480 II（Roche Diagnostics 社製) を用いて SYBR-Green 法によっ て測定した。測定は各サンプル 3 連ずつ行った。 検量線の作成は, 地下水上清および懸濁物質よ り抽出したDNAをそれぞれのプライマーで PCR 反応を行い，増幅した産物を NucleoSpin Gel and PCR Clean-up（MACHEREY-NAGEL 社製）で精 製した。ND-1000 (NanoDrop 1000, Thermo Fisher Scientific 社製）で濃度を測定し，10倍ずつ 5 段 階希釈し, 検量線を作成した。

\section{3. 結果と考察}

\section{1 地下水水質データおよび ${ }^{15} \mathrm{~N}_{\mathrm{NO}_{3}}$, $\delta{ }^{18} \mathrm{O}_{\mathrm{NO}_{3}}$ を用いた帯水層における脱窒地 点の推定}

表 1 に2012年12月25日〜27日における各観測地 点の地下水水質データを示す。本地域の地下水の 水温は, $23^{\circ} \mathrm{C}$ 前後と比較的高いのが特徵であり,

12月の冬季の調査時期においても微生物活動に適 した環境といえる。 $\mathrm{NO}_{3}-\mathrm{N}$ をると， 7 地点にお ける平均值は $8.51 \mathrm{mg} / \mathrm{L}$ であるが, 平均值を比較 的大きく下回ったのは, No.5の6.33 mg/L, No.6 の LOQ（検出限界 $0.033 \mathrm{mg} / \mathrm{L}$ 以下）, No.7の7.97 $\mathrm{mg} / \mathrm{L}$ の 3 地点であった。次に, DO に着目する と, 7 地点の平均值が $3.2 \mathrm{mg} / \mathrm{L}$ あ゙るのに対し て, No.5〜 No.7の 3 地点の DO の平均值は1.69 $\mathrm{mg} / \mathrm{L}$ と比較的低い值を示していた。地下水中の
DO が $1 \sim 4 \mathrm{mg} / \mathrm{L}$ 以下ならば, 帯水層中の嫌気 的な微小部位で脱窒が生じていることが報告され ている(江口, 2008). しかし, この 3 地点のう ち従属栄養型脱窒の副産物である $\mathrm{HCO}_{3}{ }^{-}$が比較 的高いのは, No.5及びNo.6の 2 地点であった。 観測日は異なるが, DOCの值をみても，この 2 地点は2.3〜 $2.4 \mathrm{mg} / \mathrm{L}$ と, 全 7 地点の平均值 (1.3 $\mathrm{mg} / \mathrm{L})$ を大きく上回っている。ことから, これ ら 2 地点では, 有機物を電子供与体とする従属栄 養型の脱窒が優先化している可能性が示唆され た。

脱窒の有無を確認するため, 表 1 及び図 3 に示 す $\delta^{15} \mathrm{~N}_{\mathrm{NO}_{3}}, \quad \delta^{18} \mathrm{O}_{\mathrm{NO}_{3}}$ の值に着目する。脱窒反応が 進むにつれ, 脱窒菌は選択的に質量数の軽い窒素 並びに酸素から切り離すため, 地下水溶液中には 質量数の重い硝酸性窒素ならびに酸素が濃縮し, 結果, 同位体比も重い（高い）值へと移行する （Kendall et al., 2007）。またその際，窒素同位体 比の上昇に対する酸素同位体比の上昇割合は一 般に 1:1 から 2:1の範囲であると考えられてい る（Kendall et al., 2007）。図 3 をみると，No.5及 び No.6では， $\delta^{15} \mathrm{~N}_{\mathrm{NO}_{3}}$ は11.5〜 $17.5 \% ， \quad \delta^{18} \mathrm{O}_{\mathrm{NO}_{3}}$ は 6.6 9.4\% と他の地点と比較しても高く, 図中に 示した $1: 1$ 及び $2: 1$ の脱窒ライン範囲内に位置 していることから, これら 2 地点では脱窒が起 こっているものと推測できる。No.7に関して は, 脱窒が起こっている可能性もあるが, $\delta^{15} \mathrm{~N}_{\mathrm{NO}_{3}}, \quad \delta^{18} \mathrm{O}_{\mathrm{NO}_{3}}$ の值からは十分な確証が得られ ない結果となった。

以上まとめると, 地下水水質データや $\delta^{15} \mathrm{~N}_{\mathrm{NO}_{3}}, \quad \delta^{18} \mathrm{O}_{\mathrm{NO}_{3}}$ 分析の結果, 明確に脱窒が起 こっていると推定されたポイントは, No.5と No.6の 2 地点で, No.1, No.2, No.3及びNo.4に おいては, 脱窒が起こっている可能性は低いと考 えられる。No.7においては, 脱窒が起こってい る可能性はあるが, 明確には確認できなかった。

脱窒は比較的還元的雲囲気において起こるこ とから地下水の流速と係わりが深いとされてい る (Appelo and Postoma, 2005)。そこで, 図 4 に 調查時（2012年12月25日～27日）における地下水 位の等水位線及び地下水流動べクトル図を示す。 図をみるとわかるように，地下ダムの堤体の天端 の標高 $($ T.P. $+4 \mathrm{~m})$ に漸近するように, 地下ダム 
表 1 観測地点における地下水水質データ

Table 1 Groundwater quality data of sampling points

\begin{tabular}{cccccccccccccc}
\hline \multirow{2}{*}{ No. } & 観測地点名 & $\begin{array}{c}\text { 水位 } \\
(\mathrm{TP}+\mathrm{m})\end{array}$ & $\begin{array}{c}\text { 水温 } \\
\left({ }^{\circ} \mathrm{C}\right)\end{array}$ & $\mathrm{pH}$ & $\begin{array}{c}\mathrm{EC} \\
(\mathrm{mS} / \mathrm{cm})\end{array}$ & $\begin{array}{c}\mathrm{ORP} \\
(\mathrm{mV})\end{array}$ & $\begin{array}{c}\mathrm{DO} \\
(\mathrm{mg} / \mathrm{L})\end{array}$ & $\begin{array}{c}\mathrm{SS} \\
(\mathrm{mg} / \mathrm{L})\end{array}$ & $\begin{array}{c}\mathrm{NO}_{3}-\mathrm{N} \\
(\mathrm{mg} / \mathrm{L})\end{array}$ & $\begin{array}{c}\mathrm{HCO}_{3}^{-} \\
(\mathrm{mg} / \mathrm{L})\end{array}$ & $\begin{array}{c}\delta^{15} \mathrm{~N}_{\mathrm{NO} 3} \\
(\% \circ)\end{array}$ & $\begin{array}{c}\delta^{18} \mathrm{O}_{\mathrm{NO} 3} \\
(\% \circ)\end{array}$ & $\begin{array}{c}\mathrm{DOC} \\
(\mathrm{mg} / \mathrm{L})\end{array}$ \\
\hline 1 & 米 $9 \mathrm{C} 43$ & 4.61 & 24.3 & 7.45 & 0.776 & 284 & 5.67 & 1926 & 10.57 & 203.8 & 8.6 & 1.7 & 1.2 \\
2 & 米堤上 20 & 3.55 & 22.1 & 6.97 & 0.824 & 290 & 3.25 & 36 & 8.42 & 206.3 & 10.1 & 3.5 & 0.5 \\
3 & 西スーガー & - & 22.7 & 7.28 & 0.77 & 278 & 5.63 & 2 & 10.60 & 203.8 & 8.6 & 2.7 & 0.7 \\
4 & 真8E10 & 18 & 23.8 & 7.1 & 0.962 & 233 & 2.8 & 21 & 15.66 & 280.0 & 8.3 & 1.3 & 0.8 \\
5 & 真 8E07 & 21.01 & 24.3 & 7.04 & 0.936 & 228 & 1.68 & 2772 & 6.33 & 307.5 & 11.5 & 6.6 & 2.3 \\
6 & 山城流 1 & 10.28 & 24.1 & 7.07 & 1.105 & -58 & 1.71 & 14 & $\mathrm{LOQ}$ & 375.0 & 17.5 & 9.4 & 2.4 \\
7 & 米堤上 15 & 4.47 & 23.3 & 7.45 & 0.89 & 251 & 1.67 & 224 & 7.97 & 210.0 & 8.6 & 4.0 & 0.9 \\
\hline
\end{tabular}

注） $\mathrm{DOC}\left(\mathrm{mgL}^{-1}\right)$ のみ 2012 年 9 月 23 日 24 日のデータ, それ以外は, 2012 年 12 月 25 日 27 日のデータ

* LOQ は検出限界。 $\mathrm{NO}_{3}-\mathrm{N}$ では $0.033 \mathrm{mg} / \mathrm{L}$ 。
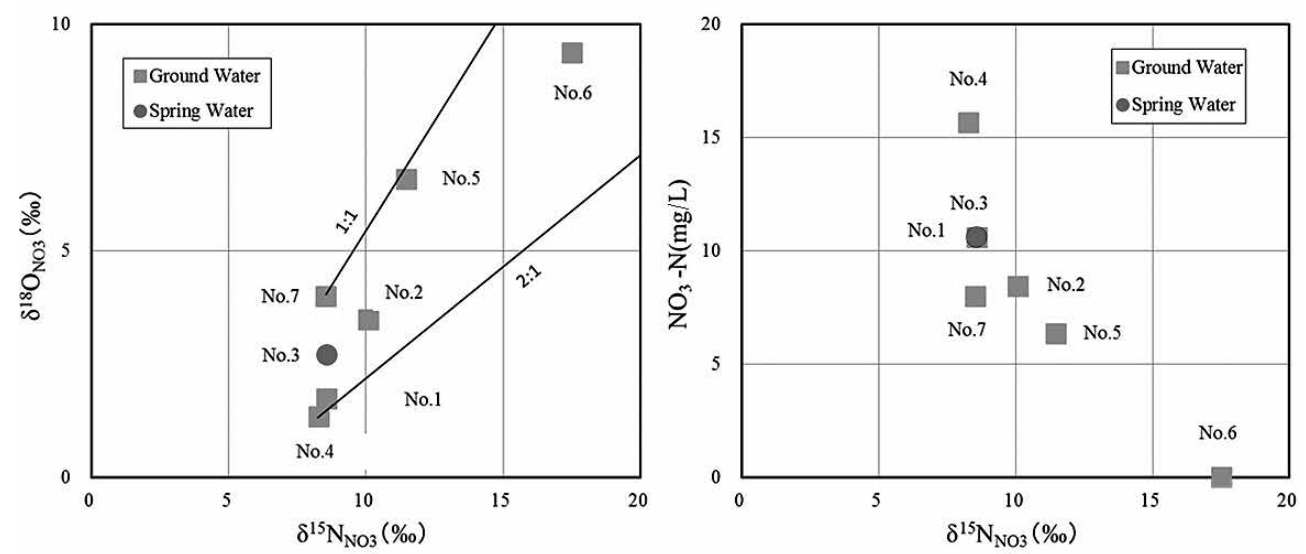

図 3 硝酸 $\left(\mathrm{NO}_{3}{ }^{-}\right)$中の酸素·窒素安定同位体比 $\left(\delta^{15} \mathrm{~N}_{\mathrm{NO}_{3}} \cdot \delta^{18} \mathrm{O}_{\mathrm{NO}_{3}}\right)$ の関係 $(\mathrm{a})$ および硝酸態窒素 $\left(\mathrm{NO}_{3}-\mathrm{N}\right)$ と窒素安定同位体比 $\left(\delta^{15} \mathrm{~N}_{\mathrm{NO}_{3}}\right)$ の関係 (b)

Fig. 3 Comparison between $\delta^{15} \mathrm{~N}_{\mathrm{NO}_{3}}$ and $\delta^{18} \mathrm{O}_{\mathrm{NO}_{3}}$ (a) and comparison between nitrate-nitrogen $\left(\mathrm{NO}_{3}-\mathrm{N}\right)$ and $\delta^{15} \mathrm{~N}_{\mathrm{NO}_{3}}$ (b)

後背地の地下水位が平準化されている。また, No.5のある真壁地区の地下水は, 断層によって 地下水流動が一時遮断され, 断層の低い部分から 流下する形で下流の米須地区に流れている。脱 窒が起こっているNo.6がある山城地区に関して は, 地形的に窪んでおり, 地下水も海側とは逆向 きに流れていることがわかる。脱窒の起こってい る可能性のあるNo.7に関しても, 地下ダムによ り地下水が滞留しやすい状況となっている。この ように, 脱窒の起こっている地点は, 地下水の滞 留時間が他の地点と比べ長くなっていると考えら れ, 地下水が還元的雾囲気になっていることが推
測できる。今後, 地下水流動解析を実施し, 滞留 時間と脱窒の関係性をより詳細に検討していく予 定である。

\section{2 地下水中の微生物相解析による脱窒に係 わる優占菌種の推察}

ここでは, 各地点の地下水試料を上清と沈殿物 に分けてDNA を抽出し, PCR-DGGEによる菌相 解析を実施し, 本地域の地下水中の優先種を同定 すると共に, 脱窒を行う微生物として報告されて いる細菌類が検出されるか検証した。

図 5 に示すように, PCR-DGGE 解析により, 


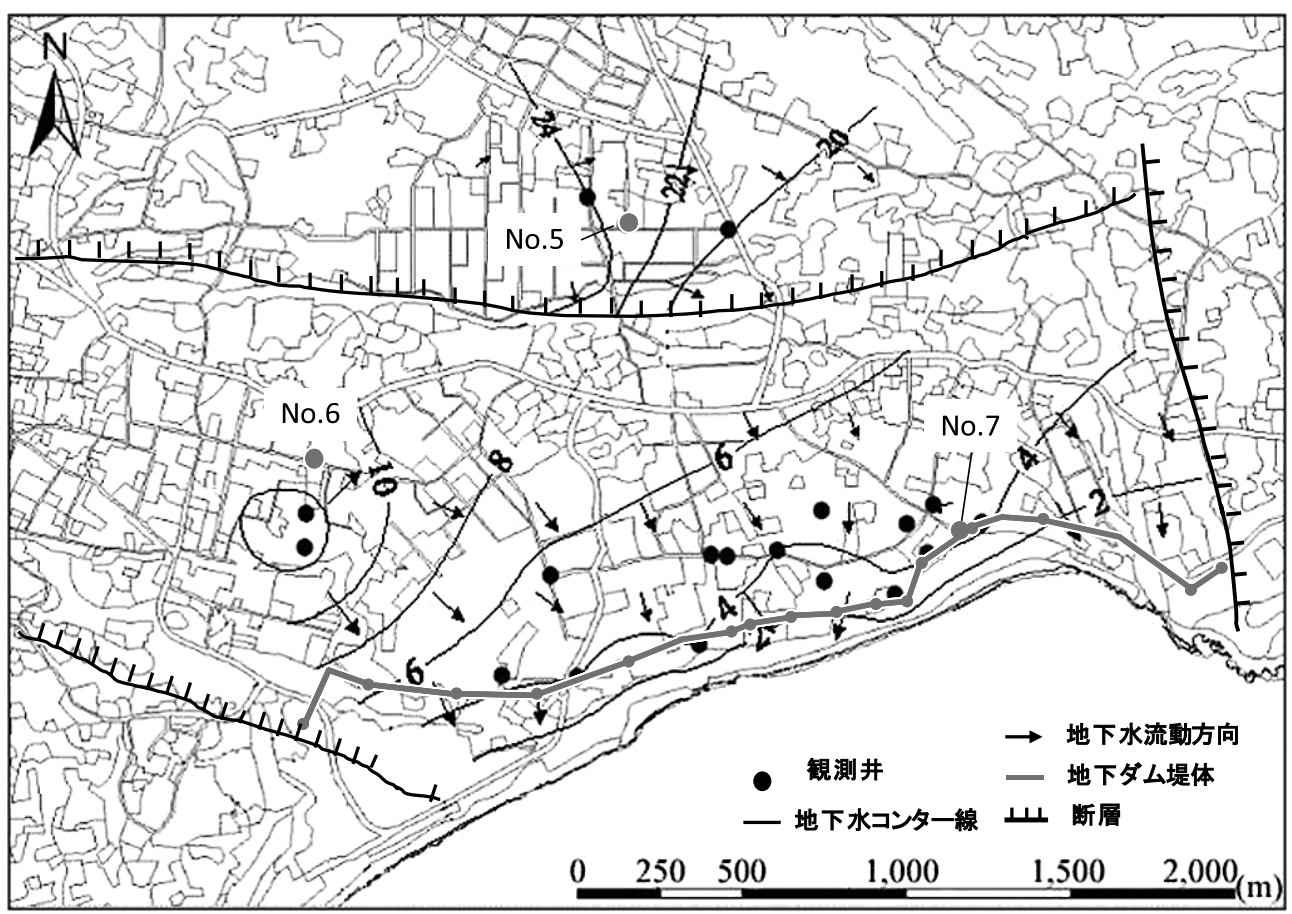

図 4 地下水流動状況（2012 年 12 月 25 日～27 日）

Fig. 4 Groundwater flow in the study site

観測地点（No.1 No.7）の地下水 7 試料の上清 （S1〜 S7）から20バンドの塩基配列情報を得るこ とができ, シークエンス解析の結果から, 地下水 試料中の細菌群集について検討をおこなった。同 じ地点の地下水試料の上清および沈殿物ともにバ ンドの数も非常に多く検出された。特に沈殿物 は、バンドをゲルから切り出し・精製を行う過程 で，単一バンドを得ることが難しく多種多様な細 菌群集の存在が示唆されたが, 今回は上清につい てのみバンドの解析を進めた。

表 2 にPCR-DGGE 解析及びシークエンス解析 から同定された地下水試料上清中の優占微生物種 を示す。 3.1 で示した地下水水質データゃ $\delta^{15} \mathrm{~N}_{\mathrm{NO}_{3}}, \quad \delta^{18} \mathrm{O}_{\mathrm{NO}_{3}}$ から脱窒ポイントであると推定 された 2 地点（No.5, No.6）における地下水試 料の上清 (S5, S6) からは, Epsilonproteobacteria 綱, Dehalococcoidetes 綱, Dehalococcoidia 綱と Candidate division TM6の細菌が検出され た。明確な脱窒が確認されなかった 5 地点 （No.1〜 No.4, No.7）における地下水試料の上清 (S1〜 S4, S7) からは, Betaproteobacteria 綱,
Epsilonproteobacteria 綱, Actinobacteria 綱, Flavobacteria 綱, Acidobacteriales 綱と未分類の細 菌が検出された。未分類に分類した細菌は, Flavobacteria 綱に属する細菌と相同性 $94 \%$ であっ た。

微生物相と各地点の DO 值を見てみると, 好 気性微生物が活発に活動するためには, $2 \mathrm{mg} / \mathrm{L}$ 以上の DO が必要であり, 一般に魚介類が生存 するためには, $3 \mathrm{mg} / \mathrm{L}$ 必要とされている（EIC ネット, 2009)。この点から見ると, No.5, No.6 と No.7の 3 地点は $2 \mathrm{mg} / \mathrm{L}$ 以下になっており, 好 気性微生物が活動しにくい環境になっていると推 測される。逆に, No.1〜 No.4の 4 地点は好気性 微生物が生息しやすい環境と推測される。各地点 の菌相を見ていくと, Actinobacteria 綱は No.1,

No.3, No.4のDOの高い地点で, 検出されてい るが, Actinobacteria 門（放線菌門）に属する 細菌は, 好気性の細菌が多く, Micrococcus 属や Arthrobacter 属は好気性として知られており（駒 形, 1985), Tetrasphaera 属も好気性として報告 されている（Maszenan et al., 2000）。No.1と No.2 


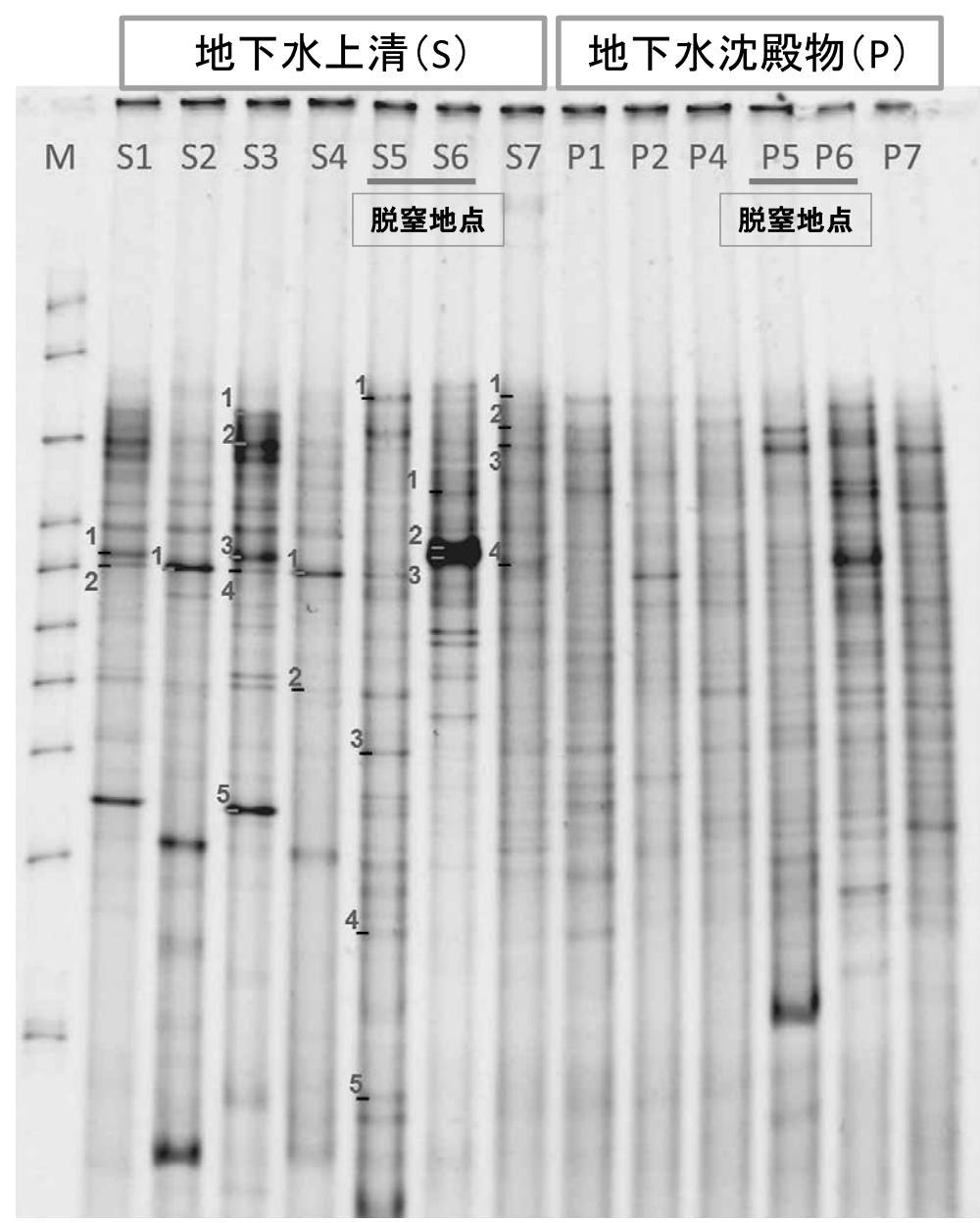

図 5 地下水試料からの細菌の 16S rDNA 配列の PCR-DGGE による解析 $M$ : マーカー, $S$ : 地下水上清, $P$ : 地下水沈殿物, 数字 : サンプリング地点 No.

Fig. 5 PCR-DGGE analysis of bacterial $16 \mathrm{~S}$ rDNA fragments from the groundwater samples.

で検出された Ralstonia 属も好気性として報告さ れている (Champoiseau et al., 2009)。

No.5, No.6で優占化している, Sulfurimonas autotrophicaは, 酸素濃度が通常より低い濃度 で生育すると報告されている (Inagaki et al., 2003)。No.5で優占化している, Dehalogenimonas lykanthroporepellens は偏性嫌気性細菌として報告 されており（Moe et al., 2009），また，TM6は嫌 気性細菌であると報告されている（McLean et al., 2013)。No.7で優占化している，Denitratisoma 属 は嫌気性であると報告されており，（Fahrbach et al., 2006), Arcobacter属は微好気から嫌気性細 菌との報告があり（Vandamme et al., 1992），ま
た，Terriglobus roseusは，好気的および嫌気的 の両方の条件で増殖することができる（Eichorst et al., 2007)。No.7で優占化している Fluviicola taffensis は偏性好気性細菌である（O'Sullivan et al., 2005)。No.5およびNo.6で優占化してい る Bacteriovorax stolpii は偏性好気性菌であるが （Baer et al., 2000），今回得られたバンドとの塩 基配列の相同性は低い。これらの菌相解析の結 果から, DOの值の高い環境下では，放線菌等の 好気性の細菌が優占化している傾向が見られ, DO の值の低いところでは，嫌気性および微好 気性の細菌を中心に好気性細菌も検出され, 周 辺の環境条件によって優占種の遷移がおこって 
表 2 PCR-DGGE 解析及びシーケンス解析から同定された地下水上清中の優占微生物種

Table 2 Identified bacteria on the primary bands in the aquifer by PCR-DGGE and sequence analysis

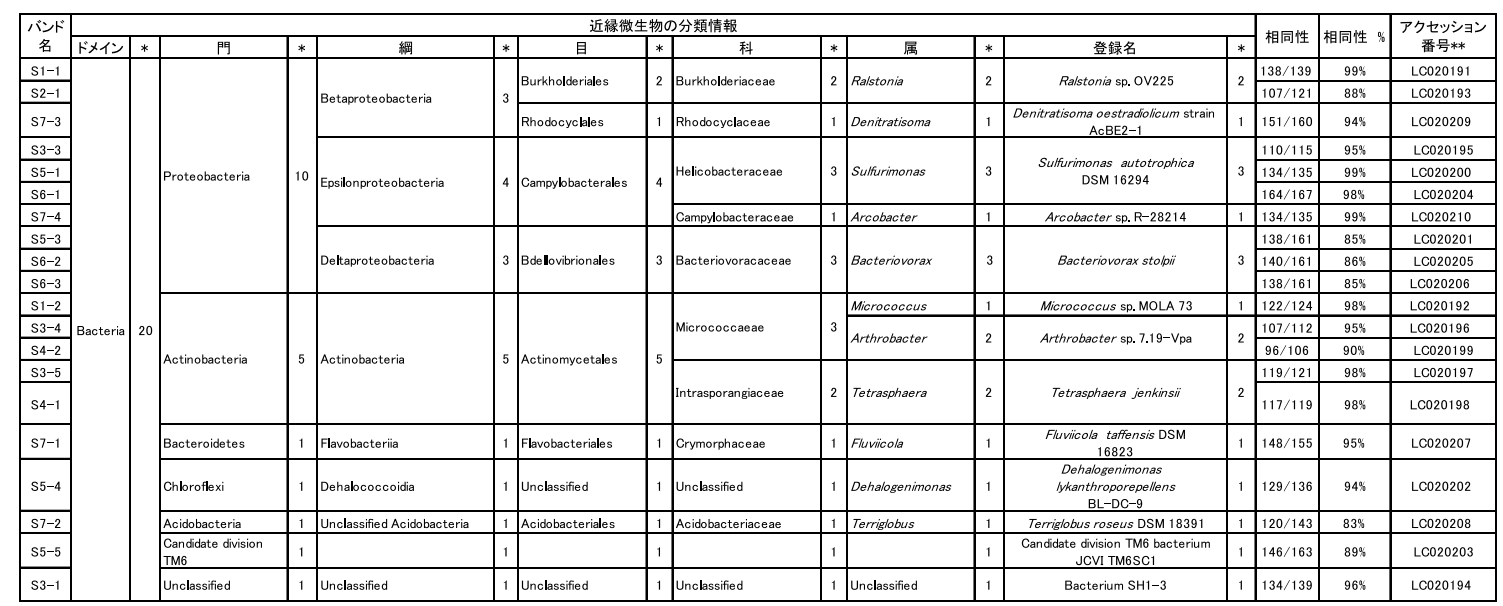

※数字は解析したバンド数を示す。※※アクセッション番号は, プライマーの配列を除くシーケンス配列の BLAST 検索の結果，一番相同性の高い株を記载した。

いる可能性が示唆された。今回, PCR-DGGE 解 析により検出された細菌の中で，脱窒能を持つ と報告されているのは，地下水上清から分離さ れたバンドである S1-1及び S2-1の Ralstonia 属 Stamper et al., 2002; Takaki et al., 2008), S1-2の Micrococcus 属 (Baumann et al., 1996), S7-3の Denitratisoma 属 (Fahrbach et al., 2006), S7-4 の Arcobacter 属（Zemft, 1997）, S3-4及び S4-2の Arthrobacter 属 (Lee et al., 2005)，S3-3， S5-1及 び S6-1の Sulfurimonas 属（Jones et al., 2008）で あった。つまり, 細菌種は異なるものの, 脱窒ポ イント，その他のポイントに係わらず，全観測地 点で脱窒能を持つと報告されている属と同じ属の 細菌が検出される結果となった。

各バンドを詳細にみていくと，No.7から検 出されたバンド S7-3は (図 5 参照), 脱窒菌 として報告のある Denitratisoma oestradiolicum (AY879297)（Fahrbach et al., 2006）および BLAST 検索で 2 番目に相同性の高い（表 2 中には 1 番の み記載) Sulfuritalea hydrogenivorans（AB552842） (Kojima and Fukui, 2011) と相同性が94\%であっ た。No.3から検出されたバンドS3-3と, 脱窒ポ イントである, No.5と No.6から検出されたバン ド S5-1及 び S6-1は, Sulfurimonas autotrophica （CP002205）（Inagaki et al., 2003）と相同性がそ れぞれ95，99，98\%であった。この Sulfurimonas autotrophicaは, 中部沖縄トラフ鳩間海丘のピス トンコア堆積物表層から分離されており，常温性 硫黄酸化細菌であると報告されている。元素状硫 黄およびチオ硫酸を唯一のエネルギー源として利 用し，10\%以下の酸素を電子受容体として生育す る絶対好気性独立栄養細菌である。沖縄卜ラフ熱 水活動域において最も存在量の多い一次生産者で あると報告されている（Inagaki et al., 2003）。硫 黄酸化細菌は, 嫌気的条件下では, パイライト $\left(\mathrm{FeS}_{2}\right)$ などを電子供与体として脱窒（硫黄脱窒） を行うことが知られている (Appelo and Postma, 2005)。しかし, 本調查地域の琉球石灰岩帯水層 中で $\mathrm{FeS}_{2}$ などは見つかっていないため, 硫黄酸 化細菌による脱窒性の有無に関しては, 今の段階 では判断できない。今後の課題とした。

その他, 他の有機物の分解や蓄積に関与して いると思われる微生物をあげると, バンド S7-1 は, gliding freshwaterから単離された, Fluviicola taffensis (CP002542) (O'Sullivan et al., 2005) と 相同性が95\%であった。バンド S5-4は，還元 された塩素化溶媒污染の地下水から単離した Dehalogenimonas lykanthroporepellens (CP002084) （Moe et al., 2009）と相同性が94\%であった。バ ンドS3-5, S4-1は, 活性污泥プロセスにおける 活性污泥の増量と形成を引き起こすと報告のあ る, Tetrasphaera jenkinsii (Y14597) (McKenzie et 
al., 2006）との相同性が98\%である。Tetrasphaera 属に属する細菌には，ポリリン酸を蓄積する ことが確認されている種も報告されている (Maszenan et al., 2000)。バンド S3-4, S4-2は, 炭化水素分解菌との報告のある, Arthrobacter sp. （JF339999）とそれぞれ，95\%と90\%である。バ ンド S5-3, S6-2, S6-3, S5-5, S7-2は, 近縁種 との塩基配列の相同性が低く，それぞれ，85\%， 86\%，85\%，89\%，83\%であり，新規性の高い細 菌群の存在が示唆され, それらの菌群の脱窒能の 有無についても今後検討していきたい。

\section{3 単離株の簡易同定と地下水および単離株 からの脱窒関連遺伝子の検出}

3.1 で示したように, 観測地点No.6における 地下水は, DO や ORP からも最も還元的な環境 であり, $\delta^{18} \mathrm{O}_{\mathrm{NO}_{3}}, \delta^{15} \mathrm{~N}_{\mathrm{NO}_{3}}$ 分析の結果, 脱窒が確 認され, PCR-DGGE解析からも脱窒菌の存在が 確認された。そこで, 本地点で採取した地下水試 料 (上清および沈殿物) から細菌を単離・培養し, 分離菌の中から63株について MALDI-Biotyperに よる細菌の簡易同定を行った。そのうち36株につ いては良好なマススペクトルが得られ，6株につ いては, ライブラリーの株とマッチした。今回, 地下水試料（上清および沈殿物）から単離した6 株は，表 3 に示すような細菌とマッチした。 Pseudomonas 属 (Zemft, 1997), Bacillus 属 (Zemft, 1997), Acidovorax 属 (Zemft, 1997), Acinetobacter 属（Cao et al., 2012）は，脱窒能を 有すると報告がある。Pseudomonas 属等は, 水中 の硝酸性窒素の微生物を利用した脱窒法に用いら れている。MALDI-Biotyperによる細菌の簡易同 定は, 環境中の微生物に関しては, データベース 数が少ないという久点もあり, 今回の実験の結果 からもマッチする株数は十数\%であった。分離株 について独自のライブラリーを構築していけれ ば, 環境分析においても有力なツールとなり得 る。

次に, 単離したPseudomonas 属の株 1 株（表 3のB4）および全地点の地下水試料（上清およ び沈殿物）から抽出したコンソーシア DNAにつ いて, 脱窒関連遺伝子と報告のある亜硝酸関連 酵素 nirS および nirK 遺伝子（Braker et al., 1998）
の有無について PCR 分析を行った。

単離株 Pseudomonas aeruginosa（表 3 の B4）に ついては, nirS 遺伝子の PCR 分析により, nirS 遺伝子を保有していることが示唆された。

\section{4 リアルタイムPCR を用いた脱窒関連遺 伝子の定量}

地下水中で脱窒が活発になると, 亜硝酸還元酵 素遺伝子（nirS, nirK）を持つ微生物が増殖する ことがしられている（Throbäck, et al., 2004）。こ こでは, 各地点の地下水試料を上清と懸濁物質に 分けて DNAを抽出し, リアルタイム PCR 法に より nirS, nirK 遺伝子を定量し， 3.1 で示した 地下水水質データや, 脱窒の指標に用いられる $\delta^{15} \mathrm{~N}_{\mathrm{NO}_{3}}, \quad \delta^{18} \mathrm{O}_{\mathrm{NO}_{3}}$ と比較し, 両者の相関関係につ いて検証した。nirS, nirK 遺伝子を定量する評価 方法としては, 地下水中の上清については, 地下 水上清 $1 \mathrm{~mL}$ 中の $\operatorname{nirS}, \operatorname{nirK}$ 遺伝子コピー数で評 価した。一方, 地下水中の懸濁物質については, 懸濁物質から抽出したDNA $1 \mu \mathrm{L}$ 中の $\operatorname{nirS}, \operatorname{nirK}$ 遺伝子コピー数として比較した。結果を図 6 に示 す。なお, 図 6 は縦軸を対数表示としている。

地下水上清中の nirS 遺伝子のコピー数が最大 を示した地点は, No.6で, 29904 copies $/ \mathrm{mL}$ と なった。次いで, 多い地点は No.7で3409 copies/ $\mathrm{mL}$ となり， $\delta^{15} \mathrm{~N}_{\mathrm{NO}_{3}}, \delta^{18} \mathrm{O}_{\mathrm{NO}_{3}}$ から脱窒が確認され たNo.5の461 copies/mLよりも大きな值を示し た。一方, nirK 遺伝子が最大を示した地点は No.7で3246 copies/mL となった。次いで, No.6 の739 copies/mL, No.5の93 copies/mLの順で

表 3 観測地点 No.6（山城流 1）から単離した細 菌の MALDI-Biotyper を用いた簡易同定結果

Table 3 Identified bacteria by MALDI-Biotyper at No.6 (Yamashiro-ryu1)

\begin{tabular}{lclc}
\hline & 試料名 & 菌種 & スコア \\
\hline B1 & S6 & Bacillus licheniformis & 2.114 \\
B2 & S6 & Acidovorax temperans & 2.190 \\
B3 & S6 & Acinetobacter tandoii & 1.742 \\
B4 & P6 & Pseudomonas aeruginosa & 2.163 \\
B5 & P6 & Pseudomonas flavescens & 1.764 \\
B6 & P6 & Bacillus licheniformis & 1.776 \\
\hline
\end{tabular}


あった。

nirS, nirK 遺伝子が検出限界以下だった地点 は, nirS 遺伝子については, No.1, No.2の地下 水の上清および懸濁物質であり, nirK 遺伝子に ついては, No.2, No.4の地下水の上清であった。

nirS 遺伝子と nirK 遺伝子とを比較すると, 地 下水の上清中では最大約 40 倍, 賏濁物質中では最 大約 7 倍の值を示し, nirS 遺伝子の方が全体的に 大きな值を示した。

次に, nirS 及び nirK 遺伝子の DNA コピー数 と, 上述した，脱窒菌法を用いて定量した $\delta^{15} \mathrm{~N}_{\mathrm{NO}_{3}}, \quad \delta^{18} \mathrm{O}_{\mathrm{NO}_{3}}$ の值との相関関係に関して検証 した。リアルタイム PCRにより定量された nirS 及び nirK 遺伝子の DNA コピー数と脱窒菌法を 用いて定量した $\delta^{15} \mathrm{~N}_{\mathrm{NO}_{3}}, \quad \delta^{18} \mathrm{O}_{\mathrm{NO}_{3}}$ の值との間の相 関関係に関する報告はこれまでなされていない。

表 4 に示すように, nirS 遺伝子に関しては, 地

a) nirS遺伝子 (地下水上清(S))

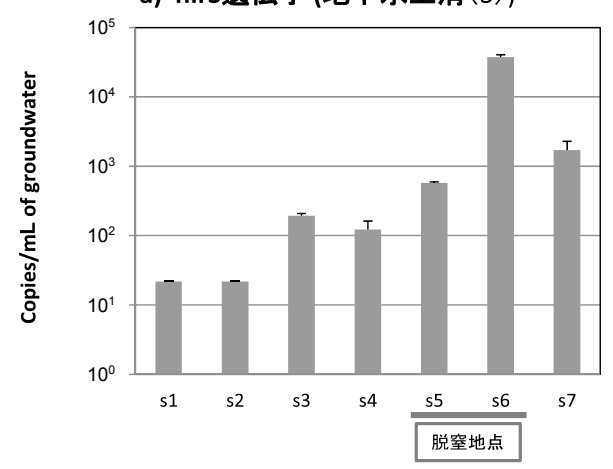

c) nirS遺伝子(地下水沈殿物 $(P)$ )

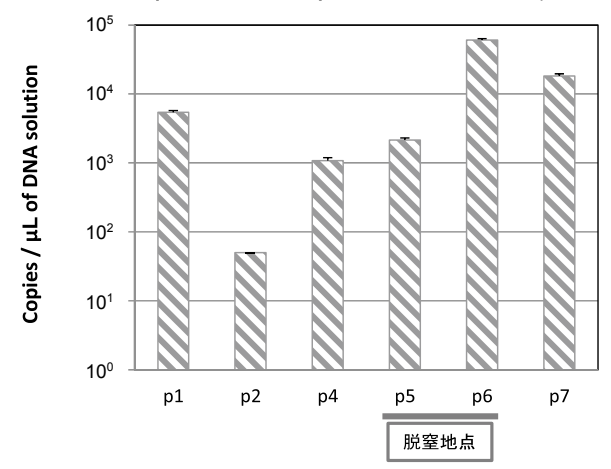

下水上清及び懸濁物質ともに $\delta^{15} \mathrm{~N}_{\mathrm{NO}_{3}}, \delta^{18} \mathrm{O}_{\mathrm{NO}_{3}}$ そ れぞれに対して高い相関がみられた。一方，nirK 遺伝子に関しては，地下水の懸濁物質中の nirS 遺伝子と同様に, $\delta^{15} \mathrm{~N}_{\mathrm{NO}_{3}}, \delta^{18} \mathrm{O}_{\mathrm{NO}_{3}}$ それぞれに対 して高い相関がみられたものの, 地下水上清中に おいては相関がみられなかった。 Rinaldo and Cutruzzola（2007）によると nirS と nirKの両方 の酵素を同時に持つ微生物は存在しないと報告さ れている。上述の 3.1 で行った菌相解析におい てはnirS, nirK遺伝子を標的としていないため, シーケンス解析の結果との比較は難しいが，本調 查地域における脱窒に関連する微生物は, nirS 遺 伝子を有する微生物によるものが卓越していると 推測できる。このように,リアルタイム PCR を 用いた脱窒関連遺伝子の定量と, $\delta^{15} \mathrm{~N}_{\mathrm{NO}_{3}}$, $\delta^{18} \mathrm{O}_{\mathrm{NO}_{3}}$ 分析とを併用することで, 地下水中の脱 窒により係わっている遺伝子を識別すると同時に

b) nirk遺伝子 (地下水上清 $(S)$ )

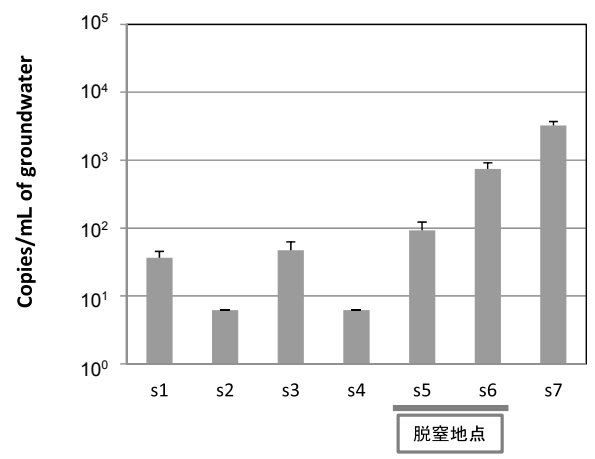

d) nirK遺伝子 (地下水沈殿物 $(\mathrm{P})$ )

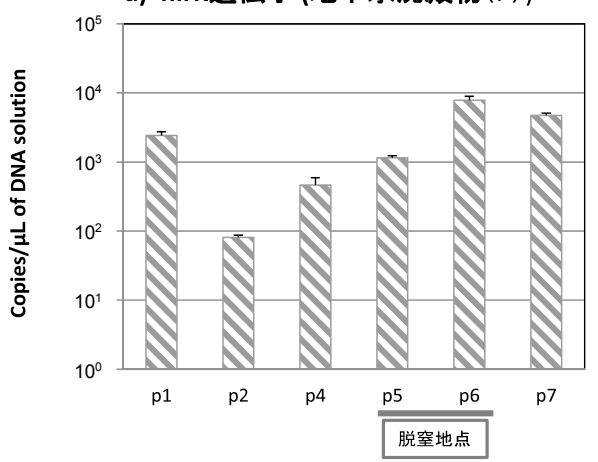

図 6 リアルタイム PCR による地下水（上清および沈殿物）中の nirS および nirK 遺伝子のコピー数

図の横軸：サンプリング地点 No., S : 地下水上清, P : 地下水沈殿物

Fig. 6 The copy number of nirS or nirk genes of the microbial consortia in the groundwater (supernatant solution and precipitation), which was determined by real-time PCR. 
表 4

地下水中の上清および沈殿物中の亜硝酸還 元酵素遺伝子 (nirS, nirK) と $\delta{ }^{15} \mathrm{~N}_{\mathrm{NO}_{3}}$, $\delta^{18} \mathrm{O}_{\mathrm{NO}_{3}}$ の相関係数

Table 4 The correlation between nirk/nirS gene dosage that has been detected by RT-PCR and the value of the $\delta{ }^{15} \mathrm{~N}_{\mathrm{NO}_{3}}$ and $\delta{ }^{18} \mathrm{O}_{\mathrm{NO}_{3}}$ in supernatant solution and precipitation

\begin{tabular}{lllll}
\hline & nirS 遺伝子 & \multicolumn{3}{c}{ nirK 遺伝子 } \\
\cline { 2 - 5 } & $\begin{array}{l}\text { 地下水上清 } \\
\text { copies } / \mathrm{mL}\end{array}$ & $\begin{array}{l}\text { copies } / \mu \text { 水沈殿物 } \\
\text { con DNA }\end{array}$ & $\begin{array}{l}\text { 地下水上清 } \\
\text { copies } / \mathrm{mL}\end{array}$ & $\begin{array}{l}\text { c地下水沈殿物 } \\
\text { copies } / \mu 1 \text { of DNA }\end{array}$ \\
\hline $\boldsymbol{\delta}^{\mathbf{1 5}} \mathbf{N}_{\mathrm{NO3}}$ & 0.93 & 0.86 & -0.04 & 0.70 \\
$\boldsymbol{\delta}^{\mathbf{1 8}} \mathbf{O}_{\mathrm{NO3}}$ & 0.81 & 0.77 & 0.16 & 0.68 \\
\hline *サンプル数 $\mathrm{n}$ 地下水上清 $: \mathrm{n}=7$, 地下水沈殿物 : $\mathrm{n}=6$
\end{tabular}

遺伝子量を定量することが可能となる。

また, 地下水水質データや $\delta^{15} \mathrm{~N}_{\mathrm{NO}_{3}}, \delta^{18} \mathrm{O}_{\mathrm{NO}_{3}}$ か らは脱窒が起こっていると明確に確認できなかっ たNo.7に拈いては, 地下水上清中の nirK 遺伝子 は全地点の中で一番高い值を示している。No.7 は, 月 1 回の定期観測の結果得られた地下水水質 データを用いた多変量解析の結果からも, 脱窒が 起こっている可能性が高い地点となっており（安 元ほか, 2013), 本手法により, 潜在的な脱窒地 点の推定が可能となりえる可能性がある。今後 は，赤木ほか（2005）が報告しているような，地 下水流動及び微生物が行う酸化還元反応を考慮し た多成分化学反応モデル等のパラメータとして活 用し, 地下水流域における脱窒量の推定が可能な モデルの開発等に繋げていきたいと考えている。

\section{4. まとめ}

本研究では, 沖縄本島南部地域の琉球石灰岩带 水層において, 地下水水質デー夕と硝酸中の窒素 及び酸素同位体比 $\left(\delta^{15} \mathrm{~N}_{\mathrm{NO}_{3}}, \delta^{18} \mathrm{O}_{\mathrm{NO}_{3}}\right)$ を測定す ることで脱窒・非脱窒ポイントを推定すると共 に, PCR-DGGE 解析や PCR 等の微生物相解析を 通じて, 带水層中の脱窒に係わる優占種の同定 と, 優先種の脱窒関連遺伝子の検出を試みた。

地下水水質データ及び $\delta^{15} \mathrm{~N}_{\mathrm{NO}_{3}}, \delta^{18} \mathrm{O}_{\mathrm{NO}_{3}}$ の分析 の結果から, 7 地点の観測地点のうち 2 地点 (No.5, No.6) で脱窒が確認された。

今回調査を実施した観測井戸において, 微生物 相解析を実施した結果，これまでに脱窒能を持つ
との報告がある Ralstonia 属, Denitratisoma 属, Micrococcus 属, Arcobacter 属, Arthrobacter 属等 の従属栄養型の脱窒を行う細菌が検出された。さ らに, 嫌気的環境下で独立栄養型の脱窒を行うこ とが知られている常温性硫黄酸化細菌 Sulfurimonas autotrophica と相同性の高い細菌が 検出された。リアルタイム PCR を用いて脱窒関 連遺伝子（nirS/nirK）の定量を行ったところ, nirK 遺伝子に比べ nirS 遺伝子の方が多く検出さ れ, 本地域の脱窒には nirS 遺伝子をもつ微生物 が優先的にかかわっていることが明らかとなっ た。また， nirS 及び nirK 遺伝子の DNA コピー 数と $\delta^{15} \mathrm{~N}_{\mathrm{NO}_{3}}, \quad \delta^{18} \mathrm{O}_{\mathrm{NO}_{3}}$ の值との間には比較的高い 相関がみられ， $\delta^{15} \mathrm{~N}_{\mathrm{NO}_{3}}, \delta^{18} \mathrm{O}_{\mathrm{NO}_{3}}$ を用いた同位体 的手法とリアルタイム PCR を用いた脱窒関連遺 伝子の定量手法を併用することが，地下水中にお ける脱窒環境の把握や脱窒の程度を推定する有効 な手法となる可能性が示唆された。

今後は, 地下水水質データや各種安定同位体比 と微生物学的解析值を微生物が行う酸化還元反応 を考慮した多成分化学反応モデル等のパラメータ として活用し, 地下水流域における脱窒量の推定 が可能なモデルの開発等に繋げていきたいと考え ている。

\section{謝辞}

本研究の遂行にあたり, 内閣府沖縄総合事務 局土地改良総合事務所, 沖縄県南部農林土木事 務所, 沖縄本島南部土地改良区の関係各位に多 大の御援助と御協力を頂いた。また，本研究 の一部は, 基盤研究 (C) 微生物活動による硝 化 ·脱窒動態の把握と水質形成機構の解明 (no. 30595202)，沖縄県の平成24年度バイオ産業活性 化支援事業補助金「硫黄酸化細菌による硝酸性窒 素污染地下水浄化技術の開発」, 科学研究費補助 金若手研究 (A)「窒素 - 硫黄 - 炭素同位体シス テマティクスを用いた脱窒メカニズム解明法の 確立」(no. 24681007) 及び科学技術振興機（JST） 戦略的創造研究推進事業チーム型研究 (CREST) 「地域水循環を踏まえた地下水持続利用システム の構築」で実施したもので得られた成果の一部で ある。ここに記して，深甚の感謝を表す。 


\section{参考文献}

赤木啓悟・細川土佐男・ゲラ・ギンギン・神野健二 ・

堤 敦・広城吉成 (2005) : 有機質土壤中に海水を浸 透させた場合の陽イオン交換および微生物による還 元反応を考慮した主要陽イオン輸送解析. 水工学論 文集，49，139-144.

EIC ネット（2009）：環境用語集. http://www.eic.or.jp/ ecoterm/?act=view\&serial=2623（2014.12.2閲覧）

江口定夫 (2008)：モデルによる土壤, 農耕地, 流域に 扔ける窒素動態の理解 3. 地形連鎖系スケールの窒 素動態 調査技法とモデル化手法. 日本土䁃肥料学雑 誌, 79, 213-227.

江口定夫（2012）：水田および浅層地下水中の脱窒によ る環境浄化. 土壤の物理性, 120, 29-38.

大楠清文 (2012)：医学検査のあゆみ, 質量分析技術 を利用した細菌の新しい同定法.モダンメディア, 58 (4), 113-122.

木崎甲子郎（1985）: 琉球弧の地質誌. 沖縄タイムズ社, 287.

駒形和男（1985）: 好気性細菌及び DNA 塩基組成の測 定. 長谷川武治編, 微生物の分類と同定下. 学会出版 センター, 99-161及び181-189.

農業環境技術研究所（2010）：PCR-DGGEによる土壤 細菌·系状菌相解析法. Ver. 3.32010 年 6 月10日改訂.

安元 純 - 聖川健斗・仲栄真史哉・砥綿泰弘 - 中野拓 治 (2013) : 多変量解析を用いた石灰岩带水層におけ る地下水水質の統計的分類, 土木学会論文集 B1（水 工学), 69 (41), I_595-I_600.

Altschul, S.F., T.L. Madden, A.A. Schaffer, J. Zhang, Z. Zhang, W. Miller and D.J. Lipman (1997): Gapped BLAST and PSI- BLAST: A new generation of protein database search programs. Nucleic Acids Research, 25, 3389-3402.

Appelo, C.A.J. and D. Postma (2005): Geochemistry, Groundwater and Pollution Second Edition. CRC Press, 458-465.

Baer, M.L., J. Ravel, J. Chun, R.T. Hill and H.N. Williams (2000): A proposal for the reclassification of Bdellovibrio stolpii and Bdellovibrio starrii into a new genus, Bacteriovorax gen. nov. as Bacteriovorax stolpii comb. nov. and Bacteriovorax starrii comb. nov., respectively. International Journal of Systematic and
Evolutionary Microbiology, 50, 219-224.

Baumann, B., M. Snozzi, A.J. Zehnder and J.R. Van Der Meer (1996): Dynamics of denitrification activity of Paracoccus denitrificans in continuous culture during aerobic-anaerobic changes. Journal of Bacteriology, 178(15), 4367-4374.

Böhlke, J.K. and J.M. Denver: (1995): Combined use of groundwater dating, chemical, and isotopic analyses to resolve the history and fate of nitrate contamination in two agricultural watersheds, Atlantic coastal plain, Maryland. Water Resources Research, 31, 2319-2339.

Braker, G., A. Fesefeldt and K.P. Witzel. (1998): Development of PCR primer systems for amplification of nitrite reductase genes (nirK and nirS) to detect denitrifying bacteria in environmental samples. Applied and Environmental Microbiology, 64, 37693775 .

Cao, H., H. Wang, S. He, R. Ou, S. Hou and X. Yang (2012): Isolation and characterization of a denitrifying Acinetobacter baumannii using $\mathrm{NO}_{2}{ }^{-} \mathrm{N}$ as nitrogen source from shrimp farming ponds. African Journal of Microbiology Research, 6(10), 2258-2264.

Champoiseau, P.G., J.B. Jones and C. Allen (2009): Ralstonia solanacearum Race 3 biovar 2 causes tropical losses and temperate anxieties. Plant Health Progress, doi:10.1094/PHP-2009-0313-01-RV.

Eichorst, S.A., J.A. Breznak and T.M. Schmidt (2007): Isolation and characterization of soil bacteria that define Terriglobus gen. nov., in the phylum Acidobacteria. Applied Environmental Microbiology, 73(8), 2708-2717.

Fahrbach, M., J. Kuever, R. Meinke, P. Kämpfer and J. Hollender (2006): Denitratisoma oestradiolicum gen. nov., sp. nov., a 17beta-oestradiol-degrading, denitrifying betaproteobacterium. International Journal of Systematic and Evolutionary Microbiology, 56(7), 1547-1552.

Hayatsu, M., K. Tago and M. Saito (2008): Various players in the nitrogen cycle: Diversity and functions of the microorganisms involved in nitrification and denitrification. Soil Science and Plant Nutrition, 54, 33-45.

Heffernan J.B., A.R. Albertin, M.L. Fork, B.G. Katz and M.J. Cohen (2012): Denitrification and inference 
of nitrogen sources in the karstic Floridan Aquifer. Biogeosciences, 9, 1671-1690.

Henry, S., E. Baudoin, J.C. López-Gutiérrez, F. MartinLaurent, A. Brauman and L. Philippot (2004): Quantification of denitrifying bacteria in soils by nirK gene targeted real-time PCR. Journal of Microbiological Methods, 59, 327-335.

Hosono, T., T. Tokunaga, A. Tsushima and J. Shimada (2014): Combined use of $\delta^{13} \mathrm{C}, \delta^{15} \mathrm{~N}$, and $\delta^{34} \mathrm{~S}$ tracers to study anaerobic bacterial processes in groundwater flow systems, Water Research, 54, 284-296.

Inagaki, F., K. Takai, H. Kobayashi, K.H. Nealson and K. Horikoshi (2003): Sulfurimonas autotrophica gen. nov., sp. nov., a novel sulfur-oxidizing $\varepsilon$-proteobacterium isolated from hydrothermal sediments in the MidOkinawa Trough. International Journal of Systematic and Evolutionary Microbiology, 53, 1801-1805.

Jones C.M., B. Stres, M. Rosenquist and S. Hallin (2008): Phylogenetic analysis of nitrite, nitric oxide, and nitrous oxide respiratory enzymes reveal a complex evolutionary history for denitrification. Biogeosciences, 9, 1671-1690.

Kandeler, E., K. Deiglmayr, D. Tscherko, D. Bru and L. Philippot (2006): Abundance of narG, nirS, nirK, and $n o s Z$ genes of denitrifying bacteria during primary successions of a glacier foreland. Applied and Environmental Microbiology, 72(9), 5957-5962.

Katsuyama, C., N. Kodo, Y. Suwa, T. Yamagishi, M. Itoh, N. Ohte, H. Kimura, K. Nagaosa and K. Kato (2008): Denitrification Activity and Relevant Bacteria Revealed by Nitrite Reductase Gene Fragments in Soil of Temperate Mixed Forest. Microbes and Environments, 23, 337-345.

Kendall, C., E.M. Elliott and S.D. Wankel (2007): Tracing anthropogenic inputs of nitrogen to ecosystems, In Stable Isotopes in Ecology and Environmental Science, 2nd ed, R.H. Michener and K. Lajtha(Eds.), Blackwell, 375-499.

Kojima, H. and M. Fukui (2011): Sulfuritalea hydrogenivorans gen. nov., sp. nov., a facultative autotroph isolated from a freshwater lake. International Journal of Systematic and Evolutionary Microbiology, 61, 1651-1655.
Lee, S.Y., S.H. Lee and Y.K. Park (2005): New nirSharboring denitrifying bacteria isolated from activated sludge and their denitrifying functions in various cultures. Journal of Microbiology and Biotechnology. 15(1), 14-21.

Mariotti, A. (1986): La dénitrification dans les eaux souterraines, principes et méthodes de son identification: une revue. Journal of Hydrology, 88, 1-23.

Mariotti, A., A. Landreau and B. Simon (1988): ${ }^{15} \mathrm{~N}$ isotope biogeochemistry and natural denitrification process in groundwater: Application to the chalk aquifer of northern France, Geochimica et Cosmochimica Acta, 52(7), 1869-1878.

Maszenan, A.M., R.J. Seviour, B.K. Patel, P. Schumann, J. Burghardt, Y. Tokiwa and H.M. Stratton (2000): Three isolates of novel polyphosphate-accumulating grampositive cocci, obtained from activated sludge, belong to a new genus, Tetrasphaera gen. nov., and description of two new species, Tetrasphaera japonica sp. nov. and Tetrasphaera australiensis sp. nov. International Journal of Systematic and Evolutionary Microbiology, 50, 593-603.

McKenzie, C.M., E.M. Seviour, P. Schumann, A.M. Maszenan, J.R. Liu, R.I. Webb, P. Monis, C.P. Saint, U. Steiner and R.J. Seviour (2006): Isolates of 'Candidatus Nostocoida limicola' Blackall et al. 2000 should be described as three novel species of the genus Tetrasphaera, as Tetrasphaera jenkinsii sp. nov., Tetrasphaera vanveenii sp. nov. and Tetrasphaera veronensis sp. nov. International Journal of Systematic and Evolutionary Microbiology, 56, 2279-2290.

McLean, J.S., M.-J. Lombardo, J.H. Badger, A. Edlund, M. Novotny, J. Yee-Greenbaum, N. Vyahhi, A.P. Hall, Y. Yang, C.L. Dupont, M.G. Ziegler, H. Chitsaz, A.E. Allen, S. Yooseph, G. Tesler, P.A. Pevzner, R.M. Friedman, K.H. Nealson, J. Craig Venter and R.S. Lasken (2013): Candidate phylum TM6 genome recovered from a hospital sink biofilm provides genomic insights into this uncultivated phylum. Proceedings of the National Academy of Sciences of the United States of America. 110(26), E2390-2399.

Moe, W.M., J. Yan, M.F. Nobre, M.S. da Costa and F.A. 
Rainey (2009): Dehalogenimonas lykanthroporepellens gen. nov., sp. nov., a reductively dehalogenating bacterium isolated from chlorinated solventcontaminated groundwater. International Journal of Systematic and Evolutionary Microbiology, 59, 26922697.

Muyzer, G., E.C. de Waal and A.G. Uitterlinden (1993): Profiling of complex microbial populations by denaturing gradient gel electrophresis analysis of polymerase chain reaction-amplified genes coding for 16S rRNA. Applied Environmental Microbiology, 59, 695-700.

O'Sullivan, L.A., J. Rinna, G. Humphreys, A.J. Weightman and J.C. Fry (2005): Fluviicola taffensis gen. nov., sp. nov., a novel freshwater bacterium of the family Cryomorphaceae in the phylum 'Bacteroidetes'. International Journal of Systematic and Evolutionary Microbiology, 55, 2189-2194.

Philippot, L., S. Hallin and M. Schloter (2007): Ecology of denitrifying prokaryotes in agricultural soil. Advances in Agronomy, 96, 249-305.

Rich, J.J., R.S. Heichen, P.J. Bottomley, K. Cromack Jr. and D.D. Myrold (2003): Community composition and functioning of denitrifying bacteria from adjacent meadow and forest soils. Applied Environmental Microbiology, 69, 5974-5982.

Rinaldo, S and F., Cutruzzola (2007): Nitrite reductases in denitrification. In Biology of the Nitrogen Cycles, H. Bothe, S.J. Ferguson and N.E. Newton (Eds.), Elesivier, 21-35.

Sigman, D.M., K.L. Casciotti, M. Andreani, C. Barford, M. Galanter and J.K. Bohlke (2001): A bacterial method for the nitrogen isotopic analysis of nitrate in sea water and freshwater. Analytical Chemistry, 73, 4145-4153.

Stamper D.M., M. Radosevich, K.B. Hallberg, S.J. Traina and O.H. Tuovinen (2002): Ralstonia basilensis M913 , a denitrifying soil bacterium capable of using s-triazines as nitrogen sources. Canadian Journal of Microbiology, 48, 12, 1089-1098.

Takaki, K., S. Fushinobu, S.W. Kim, M. Miyahara, T. Wakagi and H. Shoun (2008): Streptomyces griseus enhances denitrification by Ralstonia pickettii K50, which is possibly mediated by histidine produced during co-culture. Bioscience Biotechnology Biochemistry, 72, 163-170.

Throbäck, I.N., K. Enwall, Å. Jarvis and S. Hallin (2004): Reassessing PCR primers targeting nirS, nirK and nos $Z$ genes for community surveys of denitrifying bacteria with DGGE. Federation of European Microbiological Societies Microbiology Ecology, 49, 401-417.

Tiedje, J.M. (1994): Denitrifiers. In Methods of Soil Analysis, Part 2: Microbiological and Biochemical Properties, R. Weaver, J. Angle, and P. Bottomley (Eds.), Soil Science Society of America, 245-267.

Torrentó, C., J. Urmeneta, N. Otero, A. Soler, M. Viñas and J. Cama (2011): Enhanced denitrification in groundwater and sediments from a nitratecontaminated aquifer after addition of pyrite. Chemical Geology, 287, 90-101.

Vandamme, P., M. Vancanneyt, B. Pot, L. Mels, B. Hoste, D. Dewettinck, L. Vlaes, C. van den Borre, R. Higgins, J. Hommez, K. Kersters, J.-P. Butzler and H. Goossens (1992): Polyphasic taxonomic study of the emended genus Arcobacter with Arcobacter butzleri' comb. nov. and Arcobacter skirrowii sp. nov., an aerotolerant bacterium isolated from veterinary specimens. International Journal of Systematic Bacteriology, 42(3), 344-356.

Widory, D., W. Kloppmann, L. Chery, J. Bonnin, H. Rochdi and J.L. Guinamant (2004): Nitrate in groundwater: an isotopic multi-tracer approach. Journal of Contaminant Hydrology, 72(1-4), 165-188.

Yasumoto-Hirose, M., M. Nishijima, M.K. Ngirchechol, K. Kanoh, Y. Shizuri and W. Miki (2006): Isolation of marine bacteria by in situ culture on media-supplemented polyurethane foam. Marine Biotechnology, 8, 227-237.

Zumft, W.G. (1997): Cell biology and molecular basis of denitrification. Microbiology and Molecular Biology Reviews, 61, 533-616.

(受付：2013年11月 1 日, 受理：2014年12月18日） 